\title{
The effect of monetary policy on credit risk: evidence from the MENA region countries
}

\author{
Sherif Nabil Mahrous and Nagwa Samak \\ Department of Economics, Faculty of Economics and Political Science, \\ Cairo University, Giza, Egypt, and \\ Mamdouh Abdelmoula M. Abdelsalam \\ Department of Economics, Menoufia University, Shebin El-Kom, Egypt
}

Received 24 July 2019 Revised 16February 2020 3 April 2020 Accepted 15 April 2020

\begin{abstract}
Purpose - The purpose of this paper is to explore the effect of monetary policy on bank risk in the banking system in some MENA countries. It explores how some economic and credit indicators affect the level of risk in the banking sector. It combines many factors that could affect banks' risk appetite such as macroeconomic conditions, banks' credit size and lending growth. The authors use nonperforming loans as a proxy for banking sector risks. At first, the authors have analyzed the linear relationship between monetary policy and credit risk. As mentioned above, nonlinearity is expected in the underlying relationship, and, thus, they have investigated the nonlinear relationship to deeply analyse the relationship using the dynamic panel threshold model, as stimulated by Kremer et al. (2013). Threshold models have gained a great importance in economics and finance for modelling nonlinear behaviour. Threshold models are useful in showing the turning points in the behaviour of financial and economic indicators. This technique has been applied in this study to study the effect of monetary policy on credit risk.
\end{abstract}

Design/methodology/approach - This paper is divided into the following sections: Section 2 which previews the recent literature; Section 3 which includes some stylized facts about the relationship between credit risk and monetary policy; Section 4 which deals with the model and methodology; Section 5 which handles the data sources and discusses the results, and finally Section 6 which is the conclusion. The paper adopts dynamic panel threshold model of Kremer et al. (2013).

Findings - The results show that the relationship between monetary policy and credit risk is positive and significant to a certain threshold, 6.3. If the lending interest rate is higher than 6.3, this increases the credit risk in the banking sector, because increasing the lending interest rate imposes huge burdens on the borrowers, and, therefore, the bad loans and nonperforming loans become more likely. Thus, the MENA countries need to decrease the lending interest rate to be less than 6.3 to reduce the effect of monetary policy on credit risk. Further, these results are qualitatively robust regarding the inclusion of additional control variables, using alternative threshold variables and further endogeneity checks of the credit risk, such as Risk premium and the squared term of the lending interest rate. The results of taking the risk premium and the squared term of the lending interest rate as a threshold served the analysis and confirmed the positive relationship between monetary policy and credit risk above a certain threshold. As for the risk premium, the relationship below the threshold was negative and significant. Other related research points might be a good avenue for the future research such as applying this approach to micro data of banks from different MENA countries. Also, more sophisticated approaches like time-varying panel approach to assess the relationship over the time can be applied.

(C) Sherif Nabil Mahrous, Nagwa Samak and Mamdouh Abdelmoula M. Abdelsalam. Published in Review of Economics and Political Science. Published by Emerald Publishing Limited. This article is published under the Creative Commons Attribution (CC BY 4.0) licence. Anyone may reproduce, distribute, translate and create derivative works of this article (for both commercial and noncommercial purposes), subject to full attribution to the original publication and authors. The full terms of this licence may be seen at http://creativecommons.org/licences/by/4.0/legalcode
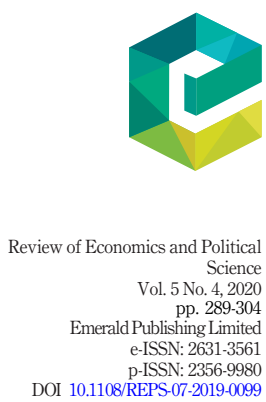
REPS

5,4

290

Originality/value - The importance of this paper lies in the fact that it does not only study the effect of time, but it also focuses on the panel data about some economic and credit indicators in the MENA region for the first time. This is because central banks in the MENA region have common characteristics and congruous level of economic growth. Therefore, to study how the monetary policy affects those countries' credit risks in their lending policies, this requires careful analysis of how the central banks in this region might behave to control default risks.

Keywords Threshold, Monetary policy

Paper type Research paper

\section{Introduction}

It is widely known that credit markets play a great role in transferring the effect of monetary policy initially to the banking sector and ultimately to the real economy. Further, it is confirmed that some borrowers could be more exposed to changes in credit conditions because increasing the interest rates may have a tightening impact on the economy if balance sheets are already weak. This generates possible nonlinearity in the effect of monetary policy. Credit channel mechanism of monetary policy affects both the efficiency of financial markets and its ability to fulfill the borrowers' and lender's needs. It also affects the extent to which borrowers face rationing in credit markets (Walsh, 2010).

Higher interest rates negatively affect firms' balance sheets, raise agency costs and decrease the efficiency of credit allocation. Changes in credit conditions are not solely reflected in the interest rate levels. Thus, it is important to understand how credit market imperfections affect the macroeconomic equilibrium and the channels through which monetary policy decisions are transferred to the real economy through the banking sector. These channels are the balance sheets channel and credit channel. The role of credit effects in the transmission of monetary policy arises because of imperfect information between parties in credit relationships (Walsh, 2010).

We should distinguish between credit channel and risk-taking channel. Credit channel has to do with lending good borrowers, while risk-taking channel has to do with lending risky borrowers within the expansionary monetary policy. Two channels have to do with the effect of monetary policy: Lending channel and balance sheets channel. Lending channel has to do with low interest rates leading to more lending, while balance sheets channel is related to those high interest rates negatively affecting borrowers' balance sheets (Diana and Carla, 2014).

Accordingly, the relationship between monetary policy and bank risk can be summarized as follows: the monetary authority uses the instruments through its monetary policy. Policy rate is considered one of the most important instruments used by the Central Banks to control the performance of banks [1]. The monetary policy affects bank risk taking. Banks should take into consideration the effects of monetary policy on their risk appetites. It also means that the monetary policy is important in determining the future of economy by affecting the credit risk. Moreover, the monetary policy impacts on banks' balance sheets by affecting risk perception. This leads to alterations and revaluation of the bank's balance sheets. As for the expansionary monetary policy, for example, investors seek higher yields, whereas banks seek higher yields as an alternative to reach their goals, and, therefore, the monetary policy authorities consider these channels while putting the financial stability goals (Kim, 2014). However, the monetary policy is not the only factor affecting banks' risk appetites.

Most central banks determine interest rates based on the target level of inflation. This happens in some developed countries and other emerging countries. Most previous studies have dealt with banks' lending processes which are negatively affected by the low interest 
rates in the short run. The turning point in the long run is that the effect turned out to be positive. This turning point has been studied by many researchers. Moreover, many studies have dealt with the effect of the tight/loose monetary policy on lending and economic growth either through handling the monetary policy in countries or through taking samples of commercial banks. Other researchers have focused on capital flows and how monetary policy affects them. Some studies have examined how non-performing loans affect economic growth. It might be noticed that excessive literature focuses on the risk-taking channel of monetary policy, especially in the USA and EU.

The aim of this paper is to explore the effect of monetary policy on bank risk in the banking system in some MENA countries. It explores how some economic and credit indicators affect the level of risk in the banking sector. It combines many factors that could affect banks' risk appetite such as macroeconomic conditions, banks' credit size and lending growth. We use nonperforming loans as a proxy for banking sector risks. At first, we have analyzed the linear relationship between monetary policy and credit risk. As mentioned above, nonlinearity is expected in the underlying relationship, and, thus, we have investigated the nonlinear relationship to deeply analyze the relationship using the dynamic panel threshold model, as stimulated by Kremer et al. (2013). Threshold models have gained a great importance in economics and finance for modelling nonlinear behaviour. Threshold models are useful in showing the turning points in the behaviour of financial and economic indicators. This technique has been applied in this study to study the effect of monetary policy on credit risk.

Thus, the importance of this paper lies in the fact that it does not only study the effect of time but also focuses on the panel data about some economic and credit indicators in the MENA region for the first time. This is because central banks in the MENA region have common characteristics and congruous level of economic growth. Therefore, to study how the monetary policy affects those countries' credit risks in their lending policies, this requires careful analysis of how the central banks in this region might behave to control default risks.

Our findings can be summarized as follows: the monetary policy is significantly affecting credit risk in the MENA countries, and this effect differs in terms of the threshold level, which is determined in our analysis. In addition, other macroeconomic variables included in the analysis have a significant impact on the level of risk in the MENA countries.

This paper is divided into the following sections: Section 2 which previews the recent literature, Section 3 which includes some stylized facts about the relationship between credit risk and monetary policy, Section 4 which deals with the model and methodology, Section 5 which handles the data sources and discusses the results, and finally Section 6 which is the conclusion.

\section{Literature}

Some empirical studies have explored the likely effect of monetary policy on credit risk. Most of these studies have discovered a negative effect of this relation. For instance, (Jimenez et al., 2009) studied the decreasing interest rates and how they affect the Spanish banks. They found out that the decreasing interest rates resulted in low default in the short term. In the medium term, the low interest rates resulted in lending high risky borrowers to gain profits, and similar findings were reached by Lopez et al. (2010). Altunbas et al. (2010) studied the link between monetary policy and bank's expected default frequencies (EDF) using data for European and US listed banks. He found evidence of a link between low interest rate and the bank risk taking. Moreover, Jimenez et al. (2014) found out that low capitalized banks increase risks in lending during the periods of low interest rates 
REPS

5,4
(Jimenez et al., 2009, 2014). Furthermore, Ioannidou et al. (2009) studied the impact of low interest rates on loan pricing. They found that banks had increased loans and offered risky borrowers low interest rates than the less risky ones. Maddaloni and Peydro (2010) found out that low interest rates would increase household loans and corporate loans with securitization.

In line with the previous papers, Geng and Zhai (2015) saw that loosening monetary policy leads to more risk taking in banks. They used panel smooth transition regression (PSTR) model with using the interest rate on deposits as an approximation of monetary policy. They found that the relationship between interest rates, reserve requirement ratio and bank risk is nonlinear, and that there is a positive correlation between interest rates and return on equity (ROE) in banks. The reserve requirement ratio has an insignificant effect on bank risk. The change of PMI (threshold level) enables the effect of both interest rates and reserve requirement ratio on bank risk in both high and low regimes of PMI. Diana and Carla (2014) used differences in differences estimator (DID) in the period from 1999 to 2007. They used a panel regression with fixed effects. They compared between the probabilities of nonpayment of loans granted during low interest rates periods, and performed the same comparison later when the interest rates became high. They came up with the conclusion that when interest rates are decreased, more credit are granted to firms and borrowers with weak or no credit history and less credit is granted to low risky borrowers. The bigger the size of the bank is, the higher the capital of the bank becomes. The higher the liquidity of the bank is, the lower the probability of it is to lend unsafe borrowers and vice versa. Further, the smaller the size of the bank is, the higher the probability of it to lend startups is.

Demire (2015) studied another proxy of bank risk which is bank rating and the results were insignificant. After taking the nonlinear interactions between monetary policy and bank risk taking into considerations, the result was that the time and the difference between the prevailing interest rate and benchmark were important in determining the relationship between monetary policy and EDF.

This is contradictory with the previous results, which confirm the negative relationship between monetary policy and credit risk. Other studies have found that the relationship between monetary policy level and credit risk within banks is positive. For instance, Kotchanan (2016) explored the effect of monetary policy on bank risk taking in Thailand by using inflation targeting policy rate and quarterly balance sheet information from 13 banks operating in Thailand in the last decade. This study found that the relationship between policy rate and bank risk taking was positive, while the unusual long low interest rate plays a part in increasing the bank's risk taking. Medium size banks seem to face the highest risk taking behaviour (as they are more sensitive to change in monetary policy) and the same is true for large and small size banks. Similarly, Altunbas et al. (2010) studied the level of interest rates before the crisis and compared this level with the level of Taylor rule interest rate used back then and before. He explored the effect of the period of low interest rates on the default and what happens when it is followed by a period of tight monetary policy. He also checked the relationship between risk taking channel and financial risk. It was found that loosening monetary policy decreases the expected default frequency. Furthermore, it was discovered that low interest rates reduce the expected default frequency (EDF) and the cost of fund. This result was also reached by Jimenez et al. (2009), very much similar to the predictions of Dubecq et al. (2009), Diamond and Rajan (2009), Adrian and Shin (2009a, 2009b). The better the economy gets, the better the firms' balance sheets become. EDF declines in this case as well. The higher the slope of the yield curve is, the higher the banks' profits and the lower the EDF become (Kashyap, 1993). Additionally, Mohamedreza et al. (2013) studied how macroeconomic variables affect credit risk (NPL). They used dynamic 
panel data model in Malaysian commercial banks from 1997 to 2012. The independent variables are GDP growth, interest rates, CPI and NPL ratio as an indicator for loan quality. It was discovered that there is positive relationship between loan growth and NPL till 2004, and with increasing credit the NPL decreased till 2008. The increase in growth and loans growth results in decrease in NPL. The inflation and lending rate increase NPL. The increase in FDI decreases local investment and increases NPL.

Regarding the MENA countries and the relationship between the monetary policy and economic growth, Espinoza and Prasad (2010) investigated the relationship between macroeconomic variables and NPLs ratio as approximation for credit risk in the Gulf Cooperation Council countries. They used dynamic panel data from 1995 to 2008 in 80 banks in the GCC countries. In addition, they studied the feedback effect of high NPLs on growth using a VAR model. The dependent variable is the logit transformation of the NPLs ratio. The independent variables are nonoil real GDP growth, stock market returns, interest rates, world trade growth, the VIX index and a 1997-1998 dummy for the Asian crisis. The panel results were that higher interest rates increase NPLs (although the effect is not significant) and higher credit reduces the NPL ratio. The VAR results were that higher nonoil growth reduces NPLs and higher interest rates increase NPLs, and the two effects are significant. Further, Valipour and Bastanzad (2015) used the data of 19 Iranian banks and applied quantile and panel data regression models. The dependent variable is NPLs, and the independent variables are real money supply, real interest rate, performing loans to total deposits one time and to total loans another time and real GDP. The results were that the higher the money supply is, the higher the NPL in different quantiles becomes. Also, the lower the real interest rate via an expansionary monetary policy is, the higher the NPL becomes.

Therefore, this study will try to fill the gap in terms of the likely nonlinear effect of monetary policy on credit risk in MENA countries.

\section{The association between credit risk and monetary policy in the MENA region}

In this part, we will show the correlation between the ratio of non-performing loans to total loans and the key variables which are the credit to private sector, the GDP per capita, the risk premium and monetary policy. We took the average of each variable across the countries in each year.

Figure 1 shows that the correlation between the ratio of nonperforming loans and each of credit to private sector and GDP per capita is negative. Also, we can observe that the regression lines give good representation for the relation between the nonperforming loans and the previous series. However, the correlation between the ratio of nonperforming loans and risk premium is not fitted very well by the regression line as many points are not going with the line in the same direction which shows flat line while points are plotted in negative form. Further, the correlation between the ratio of nonperforming loans and monetary policy is positive.

\section{Model and methodology}

The study adopts a model similar to that explored by Altunbas et al. (2010) with some changes made to be suitable for the MENA countries. The model can be represented as follows: 


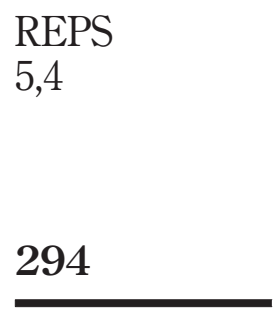

Figure 1.

Scatter plot between nonperforming loans and key variables
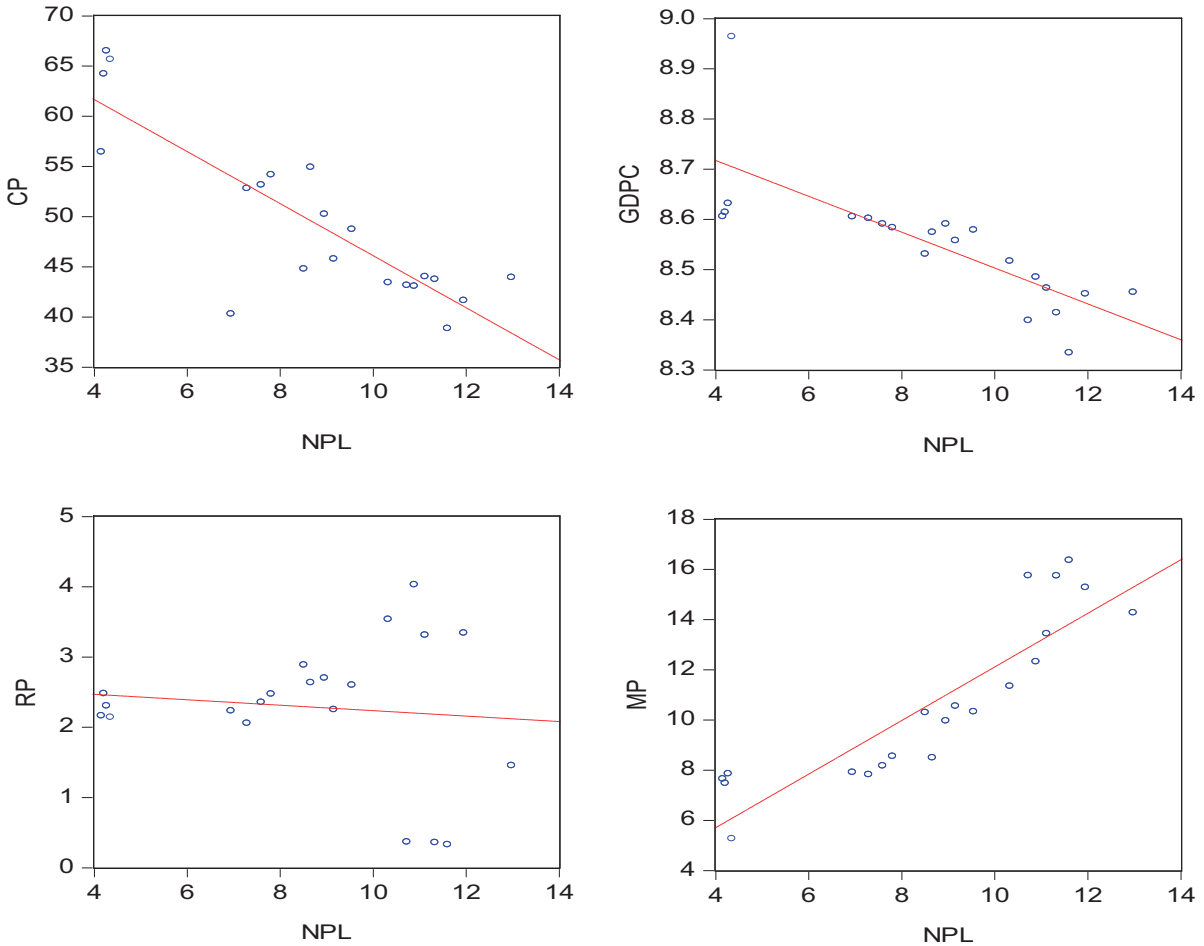

Sources: The World Development Indicators database; The Mena Region Countries Central Banks Reports

$$
N P L_{i t}=\alpha+\beta_{1} G D P C_{i t}+\beta_{2} C P I_{i t}+\beta_{3} C D P_{i t}+\beta_{4} C P_{i t}+\beta_{5} M P_{i t}+\epsilon_{i t}
$$

where NPL is the ratio of nonperforming loans to total loans as a proxy for Credit Risk; the independent variables are $G D P C_{i t}$ which refers to the GDP per capita which is gross domestic product divided by population. $\mathrm{MP}_{\text {it }}$ means the monetary policy, and we use the lending interest rate according to the lending interest rate in each country to represent monetary policy. $\mathrm{CPI}_{i t}$ is Consumer Price Index to represent inflation, and $C D P_{i t}$ refers to Credit to deposits or the percentage of Total Credit to Total deposits. $C P_{i t}$ stands for Credit granted to private sector/total credit. Furthermore, the subscript $i$ refers to different countries and $t$ is the time.

To find out dynamic relationship between monetary policy and credit risk, we performed linear analysis using the generalized method of moments GMM. Then we depended on the dynamic panel threshold model created by Kremer et al. (2013). The reasons behind depending on this method are that credit risk is expected to be dynamic and nonlinear as well. This method shows if there is a specific level of the monetary policy. In other words, it makes clear how that relationship develops with a specific level of the policy. We used the panel data instead of cross-sectional data, and, therefore, the dynamic panel threshold method became more efficient, as it contained more data about the countries and ignored the country by country effects. To estimate the threshold value, we examined the observations 
through a sample of multiple countries in the MENA region. These countries have multiple regimes, and we used varying regression slopes to identify these regimes. The data helped determine the threshold value endogenously (Demire, 2015). This method helps to find the nonlinear effects of monetary policy on credit risk. There is an assessment of the MENA countries' monetary policies to determine the most proper policy. To the best of the researcher's knowledge, this is the first study to consider the nonlinear effects of monetary policy on credit risk in the MENA region.

Effect of monetary policy on credit risk

295

\section{Data and results}

\subsection{Data}

The data were taken from many sources: The World Bank, World Development indicators database, which is the main source of the data, and the websites of the central banks of the 15 states that are taken as a sample in our model. We searched for the data in the central bank's websites of the following countries: Algeria, Bahrain, Egypt, Israel, Jordan, Kuwait, Lebanon, Morocco, Oman, Qatar, Saudi Arabia, Sudan, Tunisia, Turkey and United Arab Emirates. The researcher tried to include all the states of the MENA region in the model, but there was unavailability of the data in these states, especially the countries that suffer from political instability and wars like Libya, the West Bank, Gaza and South Sudan.

The type of the data is panel data: Balanced Panel: $\mathrm{n}=15, \mathrm{~T}=21, \mathrm{~N}=315$. They are comprised of a time series of 20 years, from 1997 to 2017 in 15 countries in the Mena Region. The data had been chosen according to their availability and the degree of economic and political stability as discussed earlier.

\subsection{Results}

In this section, we present empirical results. Table 1 shows the descriptive statistics. We can observe that the kurtosis is very high in the Lending Interest Rate series. There are heavy tails in that series and outliers. The credit to deposits series kurtosis is exactly the normal distribution kurtosis. The NPL and MP standard deviation is high due to the high percentages of NPL in Algeria and Morocco. There are also high percentages of MP in Sudan and Turkey.

Dickey-Fuller unit root test was used to check the stationarity of the different series. The null hypothesis was that the series was nonstationary, while the alternative was that the series was stationary. The unit root results are illustrated in Table 2 where CPI is nonstationary as we could not reject the null hypothesis. Thus, we used the first difference of these series. Other series were stationary in terms of their level as the null hypothesis was rejected for these series.

Table 3 shows the linear GMM [2] method estimate for the determinants of NPL in the MENA countries. We can notice that the effect of the first lag of ratio of nonperforming loans is significant and this makes clear the persistence effect of nonperforming loans level.

\begin{tabular}{|c|c|c|c|c|c|c|c|c|}
\hline & Mean & Median & Maximum & Minimum & $\mathrm{SD}$ & Skewness & Kurtosis & \\
\hline NPL & 9.52 & 6.5 & 38.15 & 1.08 & 8.20 & 1.308 & 4.18 & \\
\hline MP & 9.74 & 8 & 60 & 1.7 & 8.56 & 4.28 & 23.9 & \\
\hline $\mathrm{D}(\mathrm{CPI})$ & 95.88 & 95.11 & 190.20 & 22.17 & 0.41 & -1.45 & 13.4 & \\
\hline $\mathrm{D}(\mathrm{GDPC})$ & 9.08 & 8.97 & 11.9 & 6.83 & 1.71 & 0.075 & 1.88 & \\
\hline $\mathrm{CDP}$ & 69.04 & 66 & 89 & 14.75 & 0.35 & 0.45 & 3.09 & Table 1. \\
\hline $\mathrm{CP}$ & 3.68 & 3.92 & 4.68 & 0.48 & 0.78 & -1.58 & 5.58 & Descriptive statistics \\
\hline
\end{tabular}


REPS

5,4

296

The effect of monetary policy effect is significant and positive. This means that the policy rate is associated with the higher risk level. Inflation has a significant and negative effect. The effect of the credit to the private sector is significant and positive. Other variables have insignificant effect. The DW is around 2 which means that there is no autocorrelation, whereas $R^{2}$ is around $74 \%$. Furthermore, Hansen J-statistic showed that the estimations and instruments were valid.

Table 4 presents estimates of nonlinear model. The analysis is based on the monetary policy as a threshold variable. It can be noticed that both changes in GDP per capita and inflation have a significant and negative impact on the ratio of nonperforming loans and this means that the significant growth of high inflation in the MENA region implies less risk.

\begin{tabular}{lrr}
\hline & \multicolumn{1}{c}{ Level } & First difference \\
\hline NPL & $-2.73^{* * * *(0.003)}$ & \\
MP & $-4.685^{* * * *(0.00)}$ & $-2.01^{* * *}(0.028)$ \\
D(CPI) & $3.16(0.99)$ & $-3.204^{* * *}(0.00)$ \\
D(GDPC) & $-0.37(0.35)$ & \\
CDP & $-3.54^{* * * *(0.00)}$ & \\
CP & $-6.37 * * *(0.00)$ & \\
\hline
\end{tabular}

Table 2.

Unit root test results

\begin{tabular}{lccc}
\hline Variable & Coefficient & $t$-statistic & Prob. \\
\hline C & -4.954421 & -1.371882 & 0.1714 \\
NPL $(-1)$ & 0.791139 & 9.553979 & 0.0000 \\
MP(-1) & 0.389708 & 3.138787 & 0.0019 \\
D(GDPC) & 0.317689 & 0.937204 & 0.3496 \\
D(CPI) & -0.046362 & -2.371725 & 0.0185 \\
CDP & -0.015 & -1.27 & 0.2 \\
CP & 0.105445 & 2.394898 & 0.0174 \\
$R$-squared & 0.739839 & J-statistic & 5.672753 \\
Adjusted $R$-squared & 0.718532 & Prob (J-statistic) & 0.460828 \\
Durbin-Watson stat & 2.013975 & & \\
\hline
\end{tabular}

Table 4.

Table 3.

Dynamic panel GMM estimations

\begin{tabular}{lcrl}
\hline & Estimate & $Z$ value & \multicolumn{1}{c}{$\operatorname{Pr}(>z)$} \\
\hline Initial & 0.0971 & 2.7832 & $0.005383^{* * *}$ \\
D(GDPC) & -0.179 & -2.2154 & $0.026729^{* *}$ \\
D(CPI) & -0.1437185 & -1.9970 & $0.045822^{* *}$ \\
CDP & -0.0129 & -0.4278 & 0.668 \\
CP & -0.0416 & -1.6608 & $0.09600^{*}$ \\
Beta1 & 1.901 & 3.6402 & $0.000^{* * *}$ \\
Beta2 & 0.279 & 3.2238 & $0.001^{* * *}$ \\
Gamma & -6.825 & -2.3984 & $0.0164^{* *}$ \\
Fisher Tests for linearity (F): & & 83.0563 & $0.0008^{* * *}$
\end{tabular}

Monetary policy as a Notes: Beta 1 and Beta 2 correspond to the impact of the Lending Interest Rate on credit risk above and threshold variable below the estimated threshold level 
This is because increasing GDP per capita stimulates the macro economy and improves the financial status of borrowers. Further, concerning the negative effect of inflation on NPL, the previous empirical evidence is mixed. Some papers have found no significant relationship between both of them. For example, in the Nigerian banking industry Inekwe (2010) found no significant relationship between changes in the inflation rate and NPL. On the other hand, Khemraj and Pasha (2009) found that there is a mixed relationship between inflation and NPL. It has a negative relationship with the current time (at time $\mathrm{t}$ ) but positive relationship with one lag (at time $t-1$ ). However, both of them are not significant. The negative relationship may happen if borrowers' balance sheets are positively affected during high inflation periods. The ability of companies to repay loans will increase and will NPL decrease as well. Another scenario may happen during low inflation periods. In this case, the opposite impact will be also on the supply side as strictly low inflation levels might reduce the ability of companies to repay their loans because the low incentive for operation under less prices, and this makes NPL increase.

The credit to deposit ratio has a negative but insignificant effect. Thus, this implies that the increasing ratio of credit to deposit leading to low risk, but it is insignificant. Therefore, this effect is not considerable. Furthermore, the value of credit to the private sector has a significant and negative effect. Therefore, more credit to the private sector implied higher ability for repaying installments and then less credit risk.

In addition, Figure 2 shows that the threshold level is around 6.3 and estimates show that if the monetary policy rate is less than the threshold value, the effect of the monetary policy will be around 0.27 , which is positive and significant. If the policy is higher than the threshold level, its effect will be around 1.9. Hence, both estimates are positive and significant, because increasing the lending interest rate imposes huge burdens on the borrowers, and, therefore, the bad loans and non-performing loans become more likely. This result supports our selection of the threshold approach for the analysis. The impact of the monetary policy on credit risk increases when the interest rate is higher than the threshold. Moreover, Fisher statistic for linearity implies the rejection of the null hypothesis of the linearity of the relationship and this means that the risk analysis should be conducted by using one of the nonlinear approaches like ours.

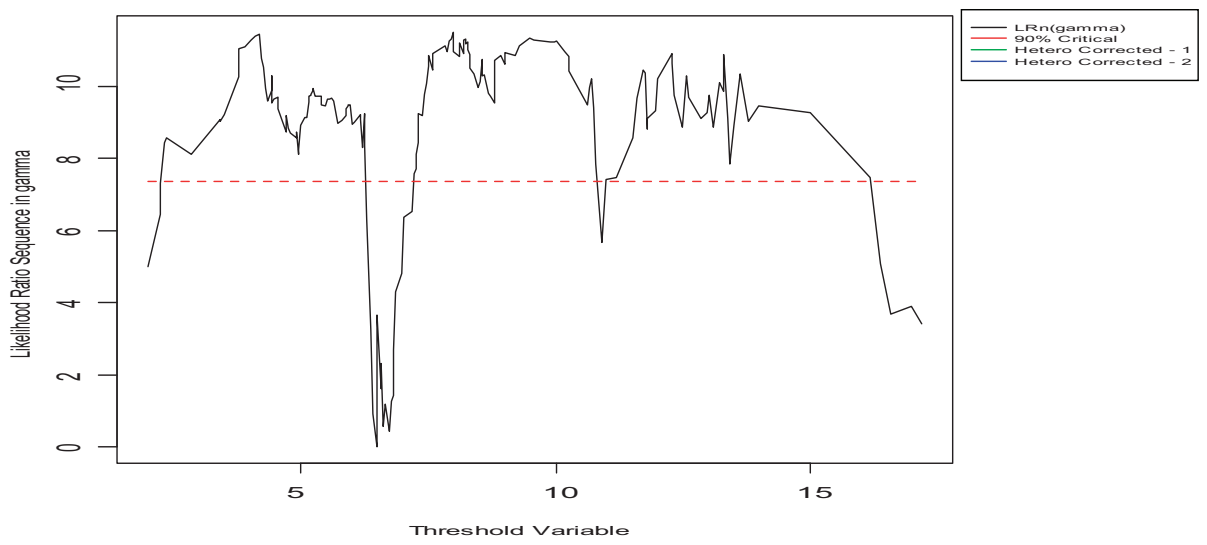

Sources: World Bank; The World Development Indicators database; The Mena Region Countries Central Banks Reports

Figure 2. Threshold level in nonlinear analysis 
REPS

5,4

\section{8}

When comparing our main result of the dynamic panel threshold with the results of some previous studies that handled the same relationship in the MENA region, we found that our main results are in line with some of them. For example, our study reached the overall result of Espinoza and Prasad (2010) study that investigated the relationship between macroeconomic variables and NPLs ratio in some banks of the Gulf Cooperation Council countries. Although the effect was not significant, they found that the higher interest rates increased NPLs as ours. We used a sample from 1997 till 2017 in 15 countries in the Mena Region, whereas the abovementioned study used micro data of 80 banks only from 1995 to 2008. In addition, we depended on a nonlinear analysis using the threshold where they used linear approach. Our results contradict the finding of Valipour and Bastanzad (2015) who found that the lower the real interest rate via an expansionary monetary policy is, the higher the NPL for a sample of 19 Iranian banks becomes.

4.2.1 Robustness tests. To explore which of the other independent variables can be used as a threshold variable, we will take other independent variables as threshold. Table 5 shows that the change in the difference of the natural logarithm of CPI is taken as a threshold variable to check the robustness of the results. It can be observed that the MP, changes in GDP per capita and credit to private sector have a negative but insignificant effect on NPL. The effect is negative and significant only for credit to deposits. Additionally, the table shows that if the CPI is less than the threshold value, its effect is negative and insignificant. If it is higher than the threshold level, its negative effect will be significant.

Table 6 shows that the GDP per capita is taken as a threshold variable to check the robustness of the results. It can be noticed that both changes in CPI and credit to private sector negatively impact the nonperforming loans level. This means that high inflation and high credit to the private sector in the MENA region imply less nonperforming loans risk. The effect is significant only for CPI, while the effect of credit to private sector is insignificant. Regarding the credit to deposit ratio, it has a positive but insignificant effect, whereas the lending interest rate has a strong significant and positive effect on NPL. This implies that the higher the lending interest rate is, the higher the risk becomes. Besides, the table shows that the threshold level is around 1 and estimates show that if the GDP per capita is less than the threshold value, its effect on NPL is positive and insignificant. Moreover, once the GDP per capita attains the threshold, its effect will be negative and significant. This means that the higher the GDP per capita is, the lower the risk becomes. This supports our decision to choose the threshold approach for the analysis.

\begin{tabular}{lccl}
\hline & Estimate & Z value & \multicolumn{1}{c}{$\operatorname{Pr}(>$ z $)$} \\
\hline Initial & -0.035082 & 4.776 & 0.0543 \\
D(GDPC & -0.08 & -2.034 & 0.307 \\
MP & -0.1060 & 2.914 & 0.393 \\
CDP & -0.0967 & 0.536 & $0.0075^{* *}$ \\
CP & 0.01227 & -1.316 & 0.768 \\
Beta1 & -0.1472 & -1.1900 & $0.001^{* *}$ \\
Beta2 & -0.0275 & 0.307 & 0.3561 \\
Gamma & 16.3905 & 2.903 & 0.0007 \\
Threshold estimate & $8.530695 \mathrm{e}+45$ & &
\end{tabular}

Table 5.

Threshold estimate $8.530695 \mathrm{e}+45$

DLCPI as a threshold Note: Beta 1 and Beta 2 correspond to the impact of the CPI on credit risk above and below the estimated variable threshold level 
Table 7 shows that the credit to deposits is taken as a threshold variable. It can be observed that both changes in CPI, credit to the private sector and GDP per capita have a negative effect on NPL level, and this means that high inflation, credit to the private sector and GDP per capita in the MENA region imply less nonperforming loans risk. The effect is significant only for GDP per capita, while the credit to private sector and CPI effects are insignificant. This comes in line with the theory because when the borrowers' GDP per capita is high, this means their standard of living and credit worthiness is high, and therefore NPL decreases. The lending interest rate has a strong significant and positive effect on NPL. This shows that the higher the lending interest rate is, the higher the risk becomes. Additionally, the table shows that the threshold level is around 3.8. Estimates show that if the credit to deposits is less than the threshold value or higher than the threshold, its effect is negative and insignificant.

Table 8 shows that the credit to private sector is taken as a threshold variable to check the robustness of the results. It can be observed that both changes in CPI and GDP per capita have a negative impact on nonperforming loans level. This means that high inflation and GDP per capita in the MENA region imply less nonperforming loans risk. The effect is significant only for CPI, while the effect of GDP per capita is insignificant. The lending interest rate has a strong, significant and positive effect on NPL. This shows that the higher the lending interest rate is, the higher the risk becomes. The effect of credit to deposits is

\begin{tabular}{lccl}
\hline & Estimate & $Z$ value & \multicolumn{1}{c}{$\operatorname{Pr}(>\mathrm{z})$} \\
\hline Initial & 0.1150686 & 3.385 & $0.0007113^{* * * *}$ \\
D(CPI) & -0.1015 & -2.8728 & $0.0040684^{* * *}$ \\
MP & 0.445 & 5.011 & $5.422 \mathrm{e}-07^{* * * *}$ \\
CDP & 0.0226028 & 0.8787 & 0.3795433 \\
CP & -0.0604239 & -1.5353 & 0.1247008 \\
Beta1 & 0.028 & 0.300 & 0.7639 \\
Beta2 & -0.192 & -2.88 & $0.003976^{* *}$ \\
Gamma & 1.224 & 1.4621 & 0.1437 \\
Threshold estimate & 0.9971602 & &
\end{tabular}

Note: Beta 1 and Beta 2 correspond to the impact of the GDP per capita on credit risk above and below the estimated threshold level

\section{Effect of monetary policy on credit risk}

299

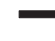

. .

\section{政}




\section{REPS}

5,4

\section{0}

positive yet insignificant. Further, the table shows that if the credit to the private sector is less than the threshold value or higher than the threshold, then its effect is negative and insignificant.

In Table 9, and to confirm the robustness of the model, we have added both the risk premium and the squared term of lending interest rate as a threshold in Table 10 to serve the analysis. The reason for adding the squared term of the lending interest is to check the effect of higher power of the policy. Similarly, adding the risk premium is important for including all types of interest rates in the analysis.

The risk premium regression shows that the effect of CPI on NPL is negative and significant. The result is the same for the other independent variables such as GDPC, credit to deposits, and bank spread. The higher the independent variables are, the lower the NPL is. The strength of the negative effect of both bank spread and GDPC is the highest. By taking the Risk premium as a threshold, the effect of risk premium is negative and significant below the threshold $4.68 \%$. That means when the risk premium increases, the NPL decreases. Once the risk premium is $4.68 \%$, its effect becomes positive and significant. That means when the risk premium increases, the NPL increases. However, when the risk premium decreases, the NPL decreases, due to the mass lending.

\begin{tabular}{lccc}
\hline & Estimate & $Z$ value & \multicolumn{1}{c}{$\operatorname{Pr}(>\mathrm{z})$} \\
\hline Initial & 0.172861 & 4.7042 & $2.549 \mathrm{e}-06^{* * * *}$ \\
D(CPI) & -0.120855 & -2.086 & $1.325 \mathrm{e}-11$ *** \\
MP & 0.371491 & 4.3985 & $1.090 \mathrm{e}-05^{* * * *}$ \\
D(GDPC) & -0.101439 & -1.9004 & 0.057379 \\
CDP & 0.034031 & -2.0864 & 0.179258 \\
Beta1 & -0.411684 & -1.3289 & 0.183894 \\
Beta2 & -0.009 & -0.265 & 0.7911 \\
Gamma & 13.218720 & 2.853 & $0.004335 * *$
\end{tabular}

Table 8.

Credit to private sector as a threshold variable
11640489

Note: Beta 1 and Beta 2 correspond to the impact of the credit to private sector on credit risk above and below the estimated threshold level
Risk premium as a threshold variable

\begin{tabular}{lccc}
\hline & Estimate & Z value & $\operatorname{Pr}(>z)$ \\
\hline Initial & 0.068 & 2.2 & $0.03^{*}$ \\
D(CPI) & -0.134 & -8 & $0.0 .000^{* * *}$ \\
D(GDPC) & -0.23 & -2 & $0.05^{*}$ \\
CDP & -0.08 & -2.3 & $0.02^{*}$ \\
Bank spread & -0.65 & -3.1 & $0.002^{* *}$ \\
Beta1 & 3.1348 & 0.9 & $0.003^{* *}$ \\
Beta2 & -0.55368 & -2.30 & 0.0000 \\
Gamma & -13.53 & -3 & $0.003^{* *}$ \\
Threshold estimate & 468.7174 & &
\end{tabular}

Note: Beta 1 and Beta 2 correspond to the impact of the risk premium on credit risk above and below the estimated threshold level 
When taking the squared term of lending interest rate as a threshold, the effect of inflation (change in logarithm of CPI) is negative and significant. The effect of credit to deposits is negative and significant. When taking the squared term of lending interest rate as a threshold, the effect is positive and insignificant below the threshold, $4.9 \%$. Once it attains the threshold, the effect is negative yet insignificant.

Effect of monetary policy on credit risk

301

\section{Conclusion}

This study analyses the effect of monetary policy on bank risk in the banking system in some MENA countries. It combines many factors that could affect banks' risk appetites such as macroeconomic conditions, banks credit size and the lending growth. We have used the nonperforming loans as a proxy for banking sector risks.

To check the nonlinear effect of monetary policy on credit risk, we used the dynamic panel threshold model. Our results show that the relationship between monetary policy and credit risk is positive and significant to a certain threshold, 6.3. If the lending interest rate is higher than 6.3, this increases the credit risk in the banking sector, because increasing the lending interest rate imposes huge burdens on the borrowers, and, therefore, the bad loans and nonperforming loans become more likely. Thus, the MENA countries need to decrease the lending interest rate to be less than 6.3 to reduce the effect of monetary policy on credit risk. Further, these results are qualitatively robust regarding the inclusion of additional control variables, using alternative threshold variables and further endogeneity checks of the credit risk, such as risk premium and the squared term of the lending interest rate. The results of taking the risk premium and the squared term of the lending interest rate as a threshold served the analysis and confirmed the positive relationship between monetary policy and credit risk above a certain threshold. As for the risk premium, the relationship below the threshold was negative and significant.

The results of this study can help the bank supervisors and economists to enhance their banking system stability and economic policies. The main policy implication drawn from the findings of the paper is that policymakers in the MENA region need to adopt a suitable monetary policy according to the risk appetite of the monetary authority of each country. They should consider the effect of their policies on the credit risk in the banking system, and the other considerations like the economic stability and inflation. For instance, in Egypt, the central bank should allow banks to take more risks and transform the policy into a more risk taking. Therefore, some loosening in the monetary policy may be of great importance in Egypt.

\begin{tabular}{lccl}
\hline & Estimate & Z value & \multicolumn{1}{c}{$\operatorname{Pr}(>$ z $)$} \\
\hline Initial & 0.03 & 0.70 & 0.5 \\
D(CPI) & -0.14 & -7.2 & $0.0000^{* * * *}$ \\
D(GDPC) & -0.14 & -1.5 & 0.12 \\
CDP & -0.09 & -2.5 & $0.01^{*}$ \\
CP & -0.002 & -0.03 & 1 \\
Beta1 & -0.1 & -0.5 & 0.6 \\
Beta2 & 0.04 & 0.3 & 0.8 \\
Gamma & 7 & 2.3 & 0.02 \\
Threshold estimate & 49020.8 & &
\end{tabular}

Notes: Beta 1 and Beta 2 correspond to the impact of the squared term of lending interest rate on credit risk above and below the estimated threshold level

Table 10.

The squared term of lending interest rate as a threshold variable 
REPS

5,4

Other related research points might be a good avenue for the future research, such as applying this approach to micro data of banks from different MENA countries. Moreover, more sophisticated approaches like time varying panel approach for assessing the relationship over the time can be applied.

\section{Notes}

1. There are other instruments that are used by central banks to affect the economy, like the money supply, if the economy is dynamically inefficient. Also, the introduction of money can make everybody better off. But if it is dynamically efficient, it is another case. Money plays a role in social security or government debt. The role of money is overstated in the OLG, as the monetary equilibrium cannot happen unless the rate of return of money dominates any other rate of return, or money is no longer valued. Thus, money disappears when the inflation rate is too high. However, money, in practice, is dominated by other assets and is still used even during the hyperinflations.

2. Dynamic form is preferred as diagnostic test and shows that nondynamic models face from some problems, such as the serial correlation problem.

\section{References}

Adrian, T. and Shin, H.S. (2009a), "Money, liquidity, and monetary policy", American Economic Review, Vol. 99 No. 2, pp. 600-605.

Adrian, T. and Shin, H.S. (2009b), "Financial intermediation and monetary economics", Federal Reserve Bank of New York Staff Reports, No. 398.

Altunbas, Y. Gambacorta, L. and Marques Lbanez, D. (2010), "Does monetary policy affect bank risk taking", BIS, working paper no 298, pp. 1-11.

Demire, A.U. (2015), Three Essays on the Nonlinear Dynamics of the Finance Growth Nexus, university of Leicester, Leicester, 75-76.

Diana, B. and Carla, S. (2014), The Risk-Taking Channel of Monetary Policy-Exploring All Avenues, Banco de Portugal, Economics and Research Departmental. 71, Lisboa, p. 4.

Espinoza, R. and Prasad, A. (2010), "Nonperforming loans in the GCC banking system and their macroeconomic effects", IMF Working paper no. 10/224.

Geng, Z. and Zhai, X. (2015), Effects of the Interest Rate and Reserve Requirement Ratio on Ban Risk in China: A Panel Smooth Transition Regression Approach, School of Finance, Zhejiang University of Finance and Economics, Hangzhou.

Inekwe, M. (2010), "Effect of inflation on non-performing loans in the banking industry in Nigeria", Journal of ARID Zone Economy, Vol. 12 No. 1.

Ioannidou, V. Ongena, S. and Peydrò, J.L. (2009), "Monetary policy and subprime lending: a tall tale of low federal funds rates, hazardous loans, and reduced loans spreads", European Banking Center Discussion. Paper, No. 2009-04S.

Jimenez, G. Ongena, S. Peydrò, J.L. and Saurina, J. (2009), "Hazardous times for monetary policy: what do Twenty-Three million bank loans say about the effects of monetary policy on credit RiskTaking?”, Banco de España, Working Paper, No. 0833.

Jimenez, G., Ongena, S., Peydró, J. and Saurina, J. (2014), "Hazardous times for monetary policy: what do twenty-three million bank loans say about the effects of monetary policy on credit risk-taking?", Econometrica, Vol. 82 No. 2, pp. 463-505.

Kashyap, A. (1993), "Monetary policy and credit conditions: evidence from the composition of external finance", American Economic Review, Vol. 83 No. 1, pp. 78-98.

Khemraj, T. and Pasha, S. (2009), "The determinants of non-performing loans: an econometric case study of Guyana”, MRPA paper No. 53128, New College of Glorida, University of Guyana. 
Kim, M. (2014), "The risk taking channel of monetary policy in Korea, and the world economy", Korea and the World Economy, Vol. 13 No. 3, pp. 449.

Kotchanan, T. (2016), The Impact of Monetary Policy on Bank Risk Taking, Thammasat University, Thailand, pp. 1-3.

Kremer, S., Bick, A. and Nautz, D. (2013), "Inflation and growth: new evidence from a dynamic panel threshold analysis", Empirical Economics, Vol. 44 No. 2, pp. 861-878.

Lopez, M. Tenjo, F. and Zárate, H. (2010), "The risk-taking channel and monetary transmission mechanism in Colombia”, Working Paper no 616, Banco de la Republica Colombia.

Maddaloni, A. and Peydro, J.-L. (2010), "Bank risk taking, securitization, supervision, and low interest rates, evidence from the euro area, and the us lending standards", working paper series no.1248, European Central Bank.

Valipour, P.M. and Bastanzad, H. (2015), "The impact of macroeconomic indicators on the nonperforming loans (case of Iran)", Journal of Money and Economy, Vol. 10

Walsh, C.E. (2010), Monetary Theory and Policy, third edition, The MIT Press, Cambridge, MA.

\section{Further reading}

Alizadeh Janvisloo, M. and Muhammad, J. (2013), "Non-performing loans sensitivity to macro variables: Panel evidence from Malaysian commercial banks", American Journal of Economics, Vol. 3.

Angeioni, I. Faia, E. and Lo Duca, M. (2014), "Monetary policy and risk taking”, June 2011.

Blanchard, O.J. and Fischer, S. (2020), Lectures on Macroeconomics, The MIT Press, Cambridge, MA, London, pp. 164-184.

Borio, C. and Zhu, H. (2008), "Capital regulation, risk-taking and monetary policy: a missing link in the transmission mechanism?", Working Paper, No.268, Bank for International Settlements.

Bruno, V. and Song Shin, H. (2012), Capital Flows and the Risk-Taking Channel of Monetary Policy, American University, Bank for International Settlements, Princeton.

Bruno, V. and Song Shin, H. (2014), Capital Flows and the Risk-Taking Channel of Monetary Policy, American University, Bank for International Settlements, Princeton.

Bain, K. and Howells, P. (2003), "Monetary economics 'policy and its' theoretical basis".

Balgova, M., Plc Khanov, A. and Skrzypinska, M. (2017), "Reducing non-performing loans: stylized facts and economic impact".

Caner, M. and Hansen, B.E. (2004), "Instrumental variable estimation of a threshold model", Econometric Theory, Vol. 20 No. 05, pp. 813-843.

Dell, A.G. Laeven, L. and Suarez Gustavo, A. (2016), “Bank leverage and monetary policy's risk taking channel, evidence from the United States", European central bank.

Drehmann, M., Borio, C., Gambacorta, L., Jiménez, G. and Trucharte, C. (2010), "Countercyclical capital buffers: exploring options, monetary and economic department”, BIS Working Papers, no.317.

Eichenbaum, M. and Evans, C.L. (1995), "Some empirical evidence on the effects of shocks to monetary policy on exchange rates", The Quarterly Journal of Economics, Vol. 110 No. 4, pp. 975-1009.

Gambacorta, L. (2011), "The risks of low interest rates invitado especial ensayos sobre políticaeconómica”, Edición Especial Riesgos EN LA Industria Bancaria, Vol. 29 No. 64, pp. 14-31.

Gilchrist, S. and Zakrajšek, E. (2012), "Credit spreads and business cycle fluctuations”, American Economic Review, Vol. 102 No. 4, pp. 1692-1720.

Hansen, B.E. (1999), "Threshold effects in non-dynamic panels: estimation, testing, and inference", Journal of Econometrics, Vol. 93 No. 2, pp. 345-368.

IMF (2015), "Monetary policy and financial stability". 
REPS

5,4

Jimenez, G. and Saurina, J. (2006), “Credit cycles, credit risk, and prudential regulation”, International Journal of Central Banking, Vol. 2 No. 2, pp. 65-98.

Monetary Dialogue (2016), "How do low and negative interest rates affect banks' activity and profitability in the euro area?", Directorate General For Internal Policies Policy Department A: Economic And Scientific Policy.

Munves, D.W. Smith, A. and Hamilton, D.T. (2010), "Banks and their EDF measures now and through the credit crisis: too high, too low, or just about right?", Capital market research, Moodys analytics, 15 .

Rajan, R.G. (2005), "Has financial development made the world riskier?", National Bureau of Economic Research. Working Paper Series, No. 11728.

Shleifer, A. and Vishny, R.W. (1997a), "A survey of corporate governance”, The Journal of Finance, Vol. 52 No. 2.

Shleifer, A. and Vishny, R.W. (1997b), "The limits of arbitrage", The Journal of Finance, Vol. 52 No. 1, pp. 35-55.

Zhang, D., Jing, C., Dickinson, D.M. and Kutan, A. (2015), "Non-performing loans, moral hazard, and regulation of the Chinese commercial banking system", Journal of Banking and Finance, Vol. 1.

\section{Corresponding author}

Sherif Nabil Mahrous can be contacted at: Sherif_448@hotmail.com

For instructions on how to order reprints of this article, please visit our website: www.emeraldgrouppublishing.com/licensing/reprints.htm

Or contact us for further details: permissions@emeraldinsight.com 